\title{
GCU
}

Glasgow Caledonian

University

University for the Common Good

\section{Analysing trademark and social media in the fashion industry: tools that impact performance and internationalization for SMEs}

Rienda, Laura; Ruiz-Fernandez, Lorena; Carey, Lindsey

Published in:

Journal of Fashion Marketing and Management

DOI:

10.1108/JFMM-03-2020-0035

Publication date:

2021

Document Version

Author accepted manuscript

Link to publication in ResearchOnline

Citation for published version (Harvard):

Rienda, L, Ruiz-Fernandez, L \& Carey, L 2021, 'Analysing trademark and social media in the fashion industry:

tools that impact performance and internationalization for SMEs', Journal of Fashion Marketing and

Management, vol. 25, no. 1, pp. 117-132. https://doi.org/10.1108/JFMM-03-2020-0035

\section{General rights}

Copyright and moral rights for the publications made accessible in the public portal are retained by the authors and/or other copyright owners and it is a condition of accessing publications that users recognise and abide by the legal requirements associated with these rights.

Take down policy

If you believe that this document breaches copyright please view our takedown policy at https://edshare.gcu.ac.uk/id/eprint/5179 for details

of how to contact us. 


\title{
ANALYSING TRADEMARK AND SOCIAL MEDIA IN THE FASHION INDUSTRY: TOOLS THAT IMPACT PERFORMANCE AND INTERNATIONALIZATION FOR SMES
}

\begin{abstract}
This research investigates the role that having a trademark and a social media presence play in the development of international activities as well as their influence on performance for small and mediumsized enterprises (SMEs) operating within the fashion sector of the UK and Ireland. Quantitative analysis was carried out by integrating information from several data sources. The hypotheses proposed in our research model are tested on a sample of 102 SMEs, applying bivariate analysis and variance-based structural equation modelling (partial least squares). The aim of this paper is to investigate the effect of trademark and social media participation on firms which varies depending on what managers of fashion related SME companies want to prioritise. Hence, these two marketing tools could be useful for managers to decide on what resources invest; to register a trademark or to be present in social media, subject to their firms' strategy and objectives.
\end{abstract}

\section{KEYWORDS}

SMEs, fashion industry, trademark, social media, performance, international business. 


\section{INTRODUCTION}

The increasing globalisation of the fashion industry has led to greater international competition. Furthermore, the emergence of new technologies in recent years has created both opportunities and challenges for fashion retailers, particularly for small and medium-sized enterprises (SMEs) whose limited resources could entail a barrier to the adoption of such technologies (Kim et al, 2013). Nowadays, SMEs deal with a dynamic environment and they need to manage different resources in order to be competitive. This environment is more complex in the fashion industry, where companies must to adapt and answer rapidly to the emerging needs of their customers. There is growing consensus amongst researchers that SMEs differ from larger companies with respect to managerial styles, scale of operations and strategic decisions (O'Cass and Weerawardena, 2009). In fact, small businesses need to deal with specific sizerelated issues and behave differently from their larger counterparts (Shuman and Seeger, 1986). In particular, SMEs encounter difficulties in their internationalisation process due to their resource-based constraints (Coviello and McAuley, 1999; Gomes-Casseres, 1997).

Developing a recognisable brand and developing social media presence are both valuable marketing tools. Despite the growing number of firms who have a registered trademark, mixed results have been reported regarding the benefits on business performance (Greenhalgh and Rogers, 2007; Krasnikov et al., 2009; Seethamraju, 2003). This relationship is particularly under-researched when the object of the research is concerned with SMEs (Agostini et al., 2014). The paucity of investigations that consider trademark as a critical factor for internationalisation adds to the contribution this paper makes to research in this area. In addition, the effect of social media in firms' decisions regarding internationalisation has still not been fully explored (Paniagua and Sapena, 2014).This research investigates the role trademark and social media 
play in the development of international activities and performance of SMEs in the UK and Ireland fashion industry.

Thus, the potential value of the use of these particular resources in SMEs, namely trademark and social media adoption, and their impact on performance and firms' international activity has scarcely been investigated within the fashion context. This study attempts to fill this research gap by exploring if fashion SMEs achieve better performance or greater internationalisation when they have a registered trademark, or if they have a presence in social media. This paper answers the following questions: Do SMEs operating within the fashion industry have higher performance when they possess a trademark and/or make use of social media? Do SMEs in the fashion industry have a greater chance of having an international presence when they possess a trademark and/or make use of social media? Is an international presence more likely for SMEs who operate in the fashion industry if they possess a trademark and/or make use of social media?

This paper contributes to research in several ways. Firstly, our sample is focused on SMEs and a limited number of papers consider this profile of firms in the context of the fashion industry. Secondly, we tested our hypotheses with a quantitative study whilst many research papers concerned with the fashion industry are commonly qualitative. There is a scarcity of quantitative papers in this area and in particular looking at SMEs (Ananda et al., 2017). Thirdly, trademark and social media are prominent marketing tools, and they are particularly important in the fashion industry due to their characteristics. Both have influence on strategy and decision-making processes within the operating structure of companies. Finally, our results offer practical implications as SME managers, who must decide to invest or not in specific resources, will obtain information about the impact different variables (trademark and social media) will have on performance and/or international activity. 
This paper is organized as follows. In the next section we review available research concerned with the relationship of trademark and social media with company performance and international activity. Next, we present the methodology and data collection procedure. Then, our results are presented and discussed. Finally, we explain the main findings, describe the principal managerial implications, and suggest future research areas related to this topic.

\section{THEORETICAL BACKGROUND}

Malem (2008) suggests that much of the UK fashion industry is made up of SMEs (in particular of less than 50 employees). Furthermore, the increasing number of these SMEs operating in an international landscape and their particular behaviours has attracted a growing amount of research attention in the past couple of decades (Cho and Jin, 2015; Fillis, 2001; Hutchison and Quinn, 2011; McAuley, 2010). Although the number of authors investigating the behaviour of SME companies has recently increased, this area of knowledge remains underdeveloped considering the influence of fashion SMEs in the UK (Hutchinson and Quinn, 2006).

Considering this context, we have framed our study following the resource-based view (RBV) of the firm, which considers that company performance is determined by the effectiveness with which it can convert resources into capabilities to achieve competitive advantage (Barney, 1991). In addition, we have considered that this theory provides the basis for analysing the link between the use of certain resources and the consequent value creation in the case of SMEs (Palacios-Marqués et al., 2015). According to this theory, some firms' resources can be considered as capabilities that enable SMEs to increase their performance (Trainor et al., 2014). Furthermore, RBV also suggests that capabilities accumulated before and during internationalisation can reduce the liability of foreignness, as well as affect post-entry performance outcomes (Giarratana and Torrisi, 2010). This implies that there is scope for firms to consider 
some intangible resources, such as trademark and social media, as important tools that could help them succeed with internationalisation.

We also examine the relationship between trademarks and social media, as intangible resources, with firm performance and international activity. The effect of these two marketing tools on company decisionmaking processes support managers in their decision regarding the advisability and extent of investment in such resources.

\section{Impact of trademark on firm performance and international activity}

Trademark and brand are closely linked (Greenhalgh and Rogers, 2007; Krasnikov et al., 2009), and considered as fundamental marketing capital within the fashion industry (Davey, Schneider and Davey, 2009). With trademark the firm uses names or symbols to identify its products to distinguish them from their competitors in a global environment (Agostini et al., 2014). In the fashion industry, strong and recognisable symbols and names allow companies to shape the emergence of successful trends and offer efficiency benefits for the whole industry (Barrère and Delabruyère, 2011).

SMEs differ from large firms with regards to their investments towards trademarks and marketing activities. Whilst large firms usually adopt a strategic view which includes long-term business goals and a delivery strategy, SMEs are often involved in day to day activities and strategic planning is sometimes hardly considered. This implies that they often adopt a reactive and emotional decision-making process (Hutchinson and Ray, 1986; Nastasiea and Mironeasa, 2016).

However, it has been ascertained that a firm's trademark and brands provide assurance to consumers creating individual shopper's identity and loyalty to products (Carpenter and Fairhurst, 2005; Dolbec and Chebat, 2013). Furthermore, some authors' highlight the value creating potential of trademarks for fashion 
companies to enable them to turn their innovation and creativity into a sustainable competitive advantage (Davey et al., 2009). This value often translates into economic profit (Greenhalgh and Rogers, 2007).

Some studies confirm the positive relationship between trademark and firm performance although they mainly focus on large firms (Greenhalgh and Rogers, 2007; Krasnikov et al., 2009; Seethamraju, 2003). Further research is needed to investigate whether trademark and firm performance are related within the context of smaller firms. Firms that invest on trademarks are associated with better quality as it allows firms to differentiate their products leading to higher returns (Agostini et al., 2014). It is also particularly relevant within the fashion industry where the position of trademarks is very significant (Davey et al., 2009; Weller, 2007). This leads to the proposal of our first hypothesis:

Hypothesis 1a. In the fashion industry, SMEs with trademarks are positively associated with higher firm performance.

Additionally, trademarks are considered a key motivation for fashion internationalisation (Wigley et al., 2005). International expansion of fashion retailers happens when a firm has a strong brand (Fernie et al., 1997; Whitehead, 1991; Zavrsnik, 2007). Nevertheless, little is known about the influence of trademarks on fashion SMEs internationalisation.

Recent research on new ventures and trademarks posits that trademarks can be positively related to the capabilities of the new ventures (Block et al., 2014; Zhou et al., 2016), their overall quality (Greenhalgh and Rogers, 2007) or simply their entry into a new markets (Giarratana and Torrisi, 2010). Entry into diverse markets entails a high level of uncertainty and high costs associated with the liability of foreignness when operating in a new market (Zaheer, 1995). Trademarks could drive the firm in this new adventure in two ways: increasing international operations because the firm has an ownership advantage 
in the home country to exploit in host countries; and expanding internationally to spread the costs of investment in their brand over a larger market (Giarratana and Torrisi, 2010).

In this study, we highlight the effect of trademark and consider that it is a push factor for the international activity of the firm, particularly for SMEs. They possess limited resources, but the marketing effort related to the company's brand is positively associated with international opportunities (Wigley et al., 2005).

Hypothesis $1 \mathrm{~b}$. In the fashion industry, SMEs with trademarks are positively associated with a higher international activity.

\section{Impact of social media on firm performance and international activity}

Many authors have considered during the last years whether it is worthwhile for companies to make an effort to integrate and use social networks as part of a company's business strategy (Paniagua and Sapena, 2014; Tiago and Veríssimo, 2014; among others). In short, it has been investigated in different contexts whether a company's participation in social media really leads to superior firm performance. In addition, other authors such as Nash (2019) have explored how social media platforms influence fashion consumer decisions in the UK retail sector. In our case, we are interested in studying whether, within the context we propose, namely for the specific case of SMEs, and in the fashion industry of the UK and Ireland, the effort of participation in social media means an increase in business performance, and if the SME's should seriously consider this aspect for their business strategies or not.

Specifically, it is worth highlighting the case of Scuotto et al. (2017) that also analyses the link between the use of social networks and the performance of SME's, specifically in the fashion industry, although they are more oriented towards the development of open innovation (Chesbrough, 2011). 
In particular, we can consider that social media allow users to communicate and generate shared content without the need for physical presence (Zhang et al., 2017). Thus, they facilitate communication, networks and the exchange of content for firms, which is why many organizations have decided to take advantage of this opportunity and incorporate social networks into their business and marketing strategies (Paniagua and Sapena, 2014). This leads us to justify the approach to the following hypothesis.

Hypothesis 2a. In the fashion industry, SMEs with social media are positively associated with a higher performance.

In relation to the impact that the use of social media by companies can have in their international activity, we want to emphasize that this link has been covered from various different perspectives (Alarcón-delAmo et al., 2016; Okazaki and Taylor, 2013; Paniagua et al., 2017). Recently it has been considered that the growth of social media could entails certain risks and challenges to international companies. This is because the movement generated by social media can mean a loss of control over the message to be conveyed by managers and marketing professionals. However, these companies are also realizing the potential of social media as a marketing tool (Alarcón-del-Amo et al., 2018).

On the other hand, authors like Paniagua et al. (2017) affirm that social networks are commonly assumed to be part of the internationalisation strategy nowadays; and that social media are generally assumed as an effective resource for improving the capabilities of companies, particularly those associated with international business.

In the same way, Alarcón-del-Amo et al., (2018), consider that the companies that sell their products in international markets face greater difficulties and uncertainties, because they act in unknown environments. Thus, social media can be considered a solution to be used to overcome those issues (Diviné 
et al., 2011) and other barriers of time and space (Constantinides et al., 2008). Therefore, we propose our last hypothesis:

Hypothesis $2 \mathrm{~b}$. In the fashion industry, SMEs with social media presence are positively associated with a higher international activity.

\section{The mediating role of international activity}

Over the past three decades, scholars have presented various descriptive models of international activity and performance. Despite of the fact that there is a little consensus about the relationship between internationalisation and firm performance, traditionally studies have considered a linear and positive relationship (Grant, 1987). Furthermore, the empirical findings in the international business literature point to a positive relationship between the degree of internationalisation of the firm and its performance (Ayal and Zif, 1979; Delios and Beamish 1999; McDougall and Oviatt 1996).

As indicated above, investment in trademark and social media should facilitate the internationalisation of SMEs, and taking into account this positive relationship between internationalisation and performance, we propose that international activity mediates the effect of trademark and social media on firm performance. Therefore, we set up the following hypotheses with the mediating effect of internationalisation:

Hypothesis 3a. In the fashion industry, international activity mediates the relationship between trademark and performance of SMEs.

Hypothesis $3 \mathrm{~b}$. In the fashion industry, international activity mediates the relationship between social media and performance of SMEs. 


\section{METHODOLOGY}

\section{Data collection}

Regarding the methodology used, we carried out a quantitative analysis by integrating information from several data sources. Firstly, we used the FAME database Bureau van Dijk to select the firms for our sample. In this database there is information about companies established in both the UK and Ireland. It contains companies' financial and business data information. We first established as the main search criteria that the companies belonged to the fashion industry. At the same time, we restricted the search to those companies that were SMEs (based on the number of employees that work in the company) and that were active at the time of the analysis. In this first iteration, we obtained a preliminary sample with information about 122 SMEs.

Secondly, we refined and completed the sample through an exhaustive analysis of each company through information gained from the same Fame database, the corporate website of the firm (if it was available) and different social media networks (also if available). Finally, our sample included 102 fashion SMEs established and operating in the UK and Ireland in the year 2018.

\section{Measures}

Trademark. This study considered the use of trademarks in order to compare if there are differences between firms with or without a registered trademark until the year 2017. This variable has the dual advantage of its objectivity and public availability (Agostini et al., 2014). We checked each firm in the website https://trademarks.ipo.gov.uk/ipo-tmowner, which contains official UK government information about intellectual property rights including patents, designs, trademarks and copyright (The Intellectual Property Office-IPO). For each company, we examined the annual number of trademarks. We used two 
measures. Firstly, the number of active registered trademark of each firm. And secondly, trademark as a dummy variable that takes the value 1 , when the firm has a registered trademark in the year 2017 , and 0 otherwise.

Social media. In order to collect the effect of social media usage, we selected two important essential tools. The first measure was the existence or not of a corporate company website (Padilla-Meléndez and del Águila-Obra, 2013). We have created a dummy variable with value of 1 , when the firm had a corporate website, and 0 , otherwise. On the other hand, we have also tried to approximate the use of social media by the company through the presence of the company in social networks such as Facebook, Twitter or Instagram (Aral et al., 2013). Other papers such as Nelson, Moore and Swanson (2019) have considered the study of Facebook, Twitter and Instagram as reference social media platforms. Thus, we have created another dummy variable with a value of 1 , when the firm has a presence on any of these different social networks (Facebook, Instagram or Twitter), and 0, when the company did not have any of these social networks.

Firm Performance. In this study, firm performance was measured by different financial indicators (the most commonly used) in order to adequately capture its value. We used two indicators to approximate the measure of this variable: one of them as part of key financial data, profit (loss) before taxation in GDP (Clatworthy and Jones, 2003); and another indicator that is present in the Profit and Loss account, EBITDA in GDP (Francis et al., 2003). These data all emanate from the FAME database. Finally, we used logarithmic transformation to normalise the values.

International activity. In this study we distinguished between firms that have or have not an international activity, in the year 2018, with the information that the FAME database provided. We consider international fashion SMEs as those that operate in more than one country (Dawson, 1994). Then, we 
created a dummy variable with the value of 1 , when the firm exports or has subsidiaries abroad, and 0 if the firm's activity is limited to their home country.

Firm size. In this study we used two variables to measure the size of a firm. First, we collected the number of employees of each firm. Secondly, in order to establish a more detailed categorization, we organised the number of employees following the OECD classification of SMEs: micro firms, with less than 10 employees; small firms, with more than 10 and less than 49 employees; and medium firms, with more than 50 and less than 249 employees (OECD, 2005).

Firm age. This variable also gives us interesting information related to the behaviour of new ventures. In this case, we measured firm age with two variables. On the one hand, we considered the total number of years that the firm had been operating since its foundation. There is a growing consensus that firms operating for 6 years and or less are new ventures (Brush and Vanderwerf, 1992; Zahra et al., 2000). In this way, we classified the firms into two groups: firms with 6 years and less of operation, namely "new firms"; and first with more than 6 years, namely "consolidated firms".

\section{Data analysis}

We started our exploration with a descriptive analysis in which we structured the existing data and presented the most relevant information in the simplest and most intuitive way. Subsequently, we carried out a bivariate analysis by comparing means of independent samples in order to contrast the presented hypotheses (hypotheses 1a, 1b, 2a and 2b), and thus present the results of the relationship between the variables under study. These analyses were carried out using SPSS statistical software package (SPSS, Version 24). 
Furthermore, we used a partial least squares (PLS) technique to complete our analysis and contrast all of our hypotheses (hypotheses 1a, 1b, 2a, 2b, 3a and 3b). This study is based on prior models but introduces new structural paths (Chin, 2010). The PLS method is the most suitable because the technique is effective with small samples (Chin and Newsted, 1999; Reinartz et al., 2009). In this case, we used the SmartPLS, version 3.2.8.

\section{RESULTS}

In this section we show the results obtained from the statistical analysis. First, we expose the most relevant results of the analysis of difference in means with independent samples. Secondly, we show the model obtained from PLS: the assessment of the measurement model (outer model); and, the estimation of the structural model (inner model).

Regarding the descriptive statistics, our sample is composed of small firms with 47 employees and with an average operating age of 22 years. Attending international activity, less than half of the companies in our sample have an international activity, only $38 \%$ of the total. It appears, therefore, that the sample is mainly constituted of relatively mature SMEs who do not operate overseas.

On the other side, the companies that have a trademark are mainly small firms $(46.2 \%$ of them) and consolidated firms $(64.3 \%$ of them). Finally, regarding the presence in social networks, $77.1 \%$ are consolidated firms, and more than $44 \%$ are medium firms.

Our first statistical analysis separates our sample amongst those companies with a trademark and those without it (Table I). First, it emerges that $32.4 \%$ of the overall companies in our sample have a trademark. Regarding the variables related with performance, only the difference in means of log EBITDA is significant ( $\mathrm{p}$-value $=0.077$ ). This shows that the firms with a trademark have a higher EBITDA than the 
firms without a trademark, and this is statistically significant. On the other hand, in the case of international activity, the difference in means is statistically significant ( $\mathrm{p}$-value $=0.08$ ). Because of this, we can affirm that those firms with trademark within our sample have more international activity, on average.

\section{Insert Table I here}

Successively, Table II shows the difference in means using the possession or not of a corporate website as a segregating variable. The percentage of SMEs in our sample with a website is $52.9 \%$. According with the "website" (the presence of a company website) variable all our differences in means are statistically significant relating to performance ( $\mathrm{p}$-value $=0.040 ; 0.036 ; 0.002)$. In the same way, we can see that there are differences between firms with and without website regarding their international activity (pvalue $=0.009$ ). This means that those SMEs with a website have a higher performance and more international activity than those which do not have a corporate website.

\section{Insert Table II here}

Finally, in Table III we can observe the difference in means of performance and internationalisation if we separate our sample among those companies with and without social networks. Thus, $47.1 \%$ of SMEs have, at least, a social network (Facebook, Instagram or Twitter). The differences in means for performance variables are statistically significant ( $\mathrm{p}$-value $=0.021$ and 0.001$)$. Furthermore, the difference in means of international activity is not significant. That means that we can't affirm that SMEs with social networks presence have more international activity.

Insert Table III here 
In order to achieve the objectives of this study and to test our hypotheses, we carried out a two-stage approach that is often used to achieve PLS path modelling: (1) the assessment of the measurement model (outer model), and (2) the estimation of the structural model (inner model) and hypothesis tests. All constructs drew on a reflective measurement model in the study, because the indicators of each constructs are correlated and interchangeable (Hair et al., 2013). The first step requires the assessment of the measurement model, which allows the relationships between the observable variables and theoretical concepts to be specified. In this step the measurement model of reflective constructs is evaluated in terms of reliability and validity. Table IV shows that all indicators have individual indicator reliability values that are greater than the level of $0.7(\lambda \geq 0.7)$ (Carmines and Zeller, 1979). Advocators of PLS-SEM (e.g., Hair et al., 2012, 2013; Sarstedt et al., 2014) suggest 'composite reliability' as a replacement for 'Cronbach's alpha' in assessing internal consistency reliability. According to Hair et al. (2013), values between 0.60 and 0.70 are considered "acceptable in exploratory research", whereas values between 0.70 and 0.95 are "satisfactory to good". Table IV, all values are $>0.7$ demonstrating internal consistency reliability. Convergent validity measures the extent to which a construct converges with its indicators by explaining the items' variance by the Average Variance Extracted (AVE) (Fornell and Larcker, 1981). Results indicated that all construct AVE values were greater than the acceptable threshold of 0.5 suggested by Hair et al. (2013).

\section{Insert Table IV here}

Discriminant validity determines the extent to which a construct is empirically distinct from other constructs in the path model, both in terms of how much it correlates with other constructs and in terms of how distinctly the indicators represent only this single construct (Sarstedt, et al., 2014). The most 
conservative criterion recommended to evaluate discriminant validity is the Fornell and Larcker (1981) criterion (Table V). Furthermore, we have checked the heterotrait-monotrait ratio of correlations (HTMT) developed by Henseler et al. (2016). These authors confirmed that this ratio is the best criteria to detect discriminant validity. To clearly discriminate between two factors, the HTMT should be significantly less than 0.85 (Henseler et al., 2016), which is the case in our sample.

\section{Insert Table Vhere}

After establishing reliability and validity, the study assessed the structural model using 5000 bootstrap resamples. The procedure consists of evaluating the collinearity; the algebraic sign, magnitude and statistical significance of the structural path coefficients and the $\mathrm{R}^{2}$ values (variance explained). Variance Inflation Factor (VIF) values was used to examine the collinearity. The result showed our model was not negatively affected by collinearity as all the values were $<5$ (Hair et al., 2013). The $\mathrm{R}^{2}$ value of each endogenous construct is a measure of the variance explained in each endogenous construct and the model's predictive accuracy. According to Falk and Miller (1992) $R^{2}$ values must be $\geq 0.10$. All $R^{2}$ values achieve the threshold. We can see in our model (Figure 1) the different $\mathrm{R}^{2}$ values and the path coefficients $(\beta)$ values.

\section{Insert Figure 1 here}

This study also assesses the mediating role of internationalisation between social media (website and social networks) and performance, and between trademark and performance. In other words, our model examines the indirect effect of social media and trademark on performance through internationalisation. The product of the coefficient approach using the bootstrapping resampling method has been used to 
examine the significance of the indirect effect (Nitzl et al., 2016). The results support the existence of a significant indirect effects between social media and performance (Table VI).

\section{Insert Table VI here}

\section{DISCUSSION}

This paper has focused on the analysis of a sample of SMEs operating in the fashion industry located in the UK and Ireland. Specifically, the objective of our study was to analyse how the application of two essential resources - a registered trademark and the use of social media- can influence the firms' in terms of their strategy and underpinning of resource allocation. Nowadays, managers should take into account the potential of these resources, as they are crucial and frequently used in the fashion industry in particular. With regards to how these resources affect the company, we have analysed if there are differences in the performance and international activity between SMEs that use a trademark and participate in social media and those that do not use these marketing tools. To carry out this analysis we used quantitative methods.

Our first hypothesis establishes that SMEs with trademarks are positively associated with a higher performance. Further studies also found a positive relationship between these two variables (Greenhalgh and Rogers, 2007; Krasnikov et al., 2009), and some of them examine trademark as an important feature for SMEs (Agostini et al., 2014; Helmers and Rogers, 2008). Through bivariate analysis we found a weak relationship between the firms with trademark and their performance. This is confirmed with the PLS analysis as it indicates an indirect effect between these variables through internationalisation. This means that having a trademark influences positively in the SMEs' performance when they have international activity. Therefore, hypothesis 1a is supported, but we must emphasize that the total effect of trademark on performance is due to the indirect effect via international activity. 
Concerning international activity, we also set up in our Hypothesis $1 \mathrm{~b}$ that the use of a trademark is related with the internationalisation of firms. The use of branding allows firms to gain competitive advantage in both domestic and foreign markets (Krasnikov et al., 2009) which is especially important for SMEs (Block et al., 2014). We have considered trademark as a push factor for international activity and our results confirm this relationship (confirming Hypothesis $1 \mathrm{~b}$ ). SMEs that have a registered trademark are more internationalised. This is pertinent for SMEs that want to consider foreign markets as an alternative for growth (Lu and Beamish, 2006) or as a particular tendency within the fashion industry (Macchion et al., 2017).

Another important result in this paper is related with the differences we found between fashion related SMEs performance and the use (or not) of social media. For both, if the firm has a corporate website and/or if it is present in social networks, the mean of the firm performance is higher. This relationship is also significant in our structural model. Hence, Hypothesis 2a could be also confirmed. Our study has evidenced the actual phenomenon of social media for firms, and recent research about this topic supports this fact (Paniagua and Sapena, 2014; Scuotto et al., 2017; Tiago and Veríssimo, 2014). The incidence of social media's use in firm performance is still under-researched and managers can legitimately ask if it would be profitable to invest in those resources. SMEs, with limited resources, could consider our results as an indicator of the direct impact of some intangible resources on the future performance of a firm.

Finally, Hypothesis $2 \mathrm{~b}$ posits that the use of social media positively influences the entry into international markets. This is true for SMEs that have a corporate website, but our results do not confirm this relationship if they only have a presence in social networks. One possible explanation of this result is related to the complex use of social networks in the fashion industry. Communication and use of social networks often imply a loss of control over the information or the message that is intended, given that 
these social networks are fuelled by a multitude of people expressing their opinions and preferences about the company. Thus, it would be plausible that companies whose target market exceeds national boundaries, find it more challenging to control their message and image, therefore they prefer not to participate in social networks trying to manage the situation and avoiding problematic situations (Alarcóndel-Amo et al., 2018). Furthermore, the additional contextualisation that is required for social media to operate in each country, due to language and cultural prescriptions, amongst other things, may also offer insight into why meaningful presence in different countries can be difficult to achieve for SMEs. Consequently, we can conclude that only the SMEs which invest in social media, through a corporate website, are more internationalised.

\section{CONCLUSIONS AND MANAGERIAL IMPLICATIONS}

In this paper we examined the influences within two important areas for SMEs: their performance and their international activity. How a trademark and social media participation could affect companies varies depending on what managers of fashion related SMEs want to prioritise. Hence, it could be useful for managers to decide on what resources to invest, to register a trademark or to be present in social media, subject to their firms' purpose.

Based on our empirical evidence, the fashion SMEs could improve their performance through two important marketing tools: registered trademark and social media. On the one hand, SMEs with a registered trademark are more present in the international markets and it also implies higher performance. On the other hand, there is not a significant relationship between SMEs with social media and a presence in international markets. Nonetheless, an important tool for the performance of SMEs in the fashion industry is social media. Therefore, SMEs who are focussing primarily on achieving a higher performance, without expansion in international markets, should definitely consider developing social 
media strategies. Furthermore, Wallace, Buil and Catalán (2020) offers implications for managers of luxury fashion brands looking to use social media, specifically Facebook, to improve the buying intent of their brands or to increase brand idealization.

\section{LIMITATIONS AND FUTURE RESEARCH}

Despite our results, this paper has some limitations that suggest potential directions for future research. One limitation is linked with the use of secondary data in our research. Although our database provided important and useful data in this study, future research based on primary data could contribute to complement the perceptions of SME managers about their performance and their internationalisation process. It would enrich our final results and allow us to include relevant variables such us international experience or social media investment. Furthermore, a consumer perspective could also be interesting and facilitates the introduction of a new point of view. The second limitation is related with the static nature of our data. It would be interesting to compile longitudinal data in order to go further with our statistical study and try to capture some time effects in the fashion industry. Finally, as the database we have used contains data relating to different industries, future research could try to replicate our analytical study in other sectors. With this, we could establish if the influence of a trademark and social media on firm performance and internationalisation was positive in different context and if the SMEs present the same behaviour in other industries. 


\section{REFERENCES}

Agostini, L., Filippini, R., and Nosella, A. (2014). Corporate and products brands: do they improve SMEs performance? Measuring Business Excellence, 18 (1), 78-91.

Alarcón-del-Amo, M., Rialp-Criado, A., and Rialp-Criado, J. (2018). Examining the impact of managerial involvement with social media on exporting firm performance. International Business Review, $27(2), 355-366$.

Alarcón-del-Amo, M., Rialp, A., and Rialp, J. (2016). Social media adoption by exporters: The export-dependence moderating role. Spanish Journal of Marketing-ESIC, 20 (2), 81-92.

Ananda, A.S., Hernández-García, Á., and Lamberti, L. (2017). SME fashion brands and social media marketing: From strategies to actions. International Journal of Web Based Communities, 13 (4), 468-498.

Aral, S., Dellarocas, C., and Godes, D. (2013). Introduction to the special issue - social media and business transformation: a framework for research. Information Systems Research, 24 (1), 3-13.

Ayal, I., and Zif, J. (1979). Market expansion strategies in multinational marketing. Journal of Marketing, 43 (2), 84-94.

Barney, J. (1991). Firm resources and sustained competitive advantage. Journal of management, $17(1), 99-120$.

Barrère, C., and Delabruyère, S. (2011). Intellectual property rights on creativity and heritage: The case of the fashion industry. European Journal of Law and Economics, 32 (3), 305-339.

Block, J.H., De Vries, G., Schumann, J.H., and Sandner, P. (2014). Trademarks and venture capital valuation. Journal of Business Venturing, 29 (4), 525-542.

Brush, C.G., and Vanderwerf, P.A. (1992). A comparison of methods and sources for obtaining estimates of new venture performance. Journal of Business Venturing, 7, 157-170. 
Carmines, E. G., and Zeller, R. A. (1979). Reliability and validity assessment (Vol. 17). Sage publications.

Carpenter, J.M., and Fairhurst, A. (2005). Consumer shopping value, satisfaction, and loyalty for retail apparel brands. Journal of Fashion Marketing and Management, 9 (3), 256-69.

Chesbrough, H.W. (2011). Bringing open innovation to services. MIT Sloan Management Review, $52(2), 85$.

Chin, W.W. (2010). How to write up and report PLS analyses. In Handbook of partial least squares pp. 655-690. Springer, Berlin, Heidelberg.

Chin, W.W., and Newsted, P. R. (1999). Structural equation modeling analysis with small samples using partial least squares. Statistical strategies for small sample research, 1 (1), 307-341.

Cho, H.J., and Jin, B., (2015). What explains small-and medium-sized apparel retailers' international market involvement? An application of Uppsala model. Fashion and Textiles, 2 (1), 21.

Clatworthy, M., and Jones, M. J. (2003). Financial reporting of good news and bad news: evidence from accounting narratives. Accounting and Business Research, 33 (3), 171-185.

Constantinides, E., Romero, C.L., and Boria, M.A.G. (2008). Social media: a new frontier for retailers? In European Retail Research (pp. 1-28). Gabler Verlag, Wiesbaden.

Coviello, N. E., and McAuley, A. (1999). Internationalisation and the smaller firm: a review of contemporary empirical research. MIR: Management International Review, 39 (3), 223-256.

Davey, J., Schneider, L., and Davey, H. (2009). Intellectual capital disclosure and the fashion industry. Journal of Intellectual Capital, 10 (3), 401-424.

Dawson, J.A. (1994). Internationalization of retailing operations. Journal of Marketing Management, 10, 267-82. 
Delios, A., and Beamish, P.W. (1999). Geographic scope, product diversification, and the corporate performance of Japanese firms. Strategic Management Journal 20 (8), 711-727.

Diviné, M., Schumacher, M., and Stal-Le Cardinal, J. (2011). Learning virtual teams: how to design a set of Web 2.0 tools? International Journal of Technology Management, 55 (3/4), 297-308.

Dolbec, P-Y., and Chebat, J-C. (2013). The impact of a flagship vs. a brand store on brand attitude, brand attachment and brand equity. Journal of Retailing, 89 (4), 460-466.

Falk, R.F., and Miller, N.B. (1992). A primer for soft modeling. University of Akron Press.

Fernie, J., Moore, C., Lawrie, A., and Hallsworth, A. (1997). The internationalisation of the high fashion brand: the case of central London. Journal of Product \& Brand Management, 6 (3), 151-162.

Fornell, C., and Larcker, D.F. (1981). Evaluating structural equation models with unobservable variables and measurement error. Journal of Marketing Research, 18 (1), 39-50.

Francis, J., Schipper, K., and Vincent, L. (2003). The relative and incremental explanatory power of earnings and alternative (to earnings) performance measures for returns. Contemporary Accounting Research, 20 (1), 121-164.

Giarratana, M.S., and Torrisi, S. (2010). Foreign entry and survival in a knowledge-intensive market: Emerging economy countries' international linkages, technology competences, and firm experience. Strategic Entrepreneurship Journal, 4, 85-104.

Gomes-Casseres, B. (1997). Alliance strategies of small firms. Small Business Economics, 9 (1), $33-44$.

Grant, R.M. (1987). Multinationality and performance among British manufacturing companies. Journal of International Business Studies, 18 (3), 79-89.

Greenhalgh, C., and Rogers, M. (2007). Trade Marks and Performance in UK Firms: Evidence of Schumpeterian Competition through Innovation. Oxford Intellectual Property Research Centre, Oxford. 
Hair, J.F., Jr., Hult, G.T.M., Ringle, C.M., and Sarstedt, M. (2013). A primer on Partial Least Squares Structural Equation Modeling (PLS-SEM). Thousand Oaks: Sage.

Hair, J.F. Jr, Sarstedt, M., Hopkins, L., and Kuppelwieser, V. (2014). Partial least squares structural equation modeling (PLS-SEM) An emerging tool in business research. European Business Review, 26 (2), $106-121$.

Hair, J.F., Jr., Sarstedt, M., Ringle, C.M., and Mena, J.A. (2012). An assessment of the use of partial least squares structural equation modeling in marketing research. Journal of the Academy of Marketing Science, 40 (3), 414-433.

Helmers, C., and Rogers, M. (2008). Innovation and the survival of new firms across British regions'. Department of Economics Discussion Paper Number 416, Oxford University.

Henseler, J., Ringle, C. M., and Sarstedt, M. (2016). Testing measurement invariance of composites using partial least squares. International Marketing Review, 33 (3), 405-431.

Hutchinson, K., and Quinn, B. (2011). Identifying the characteristics of small specialist international retailers. European Business Review, 23 (3), 14-327.

Hutchinson, K., Quinn, B., and Alexander, N. (2006). SME retailer internationalisation: case study evidence from British retailers. International Marketing Review, 23 (1), 25-53.

Hutchinson, P., and Ray, G. (1986). Surviving the financial stress of small enterprise growth. In Curran, J., Stanworth, J., and Watkins, D. (Eds), The Survival of the Small Firm. Volume 1: The Economics of Survival and Entrepreneurship, Gower Publishing, Aldershot, 53-71.

Kim, H.D., Lee, I., and Lee, C.K. (2013). Building Web 2.0 enterprises: A study of small and medium enterprises in the United States. International Small Business Journal, 31 (2), 156-174.

Krasnikov, A., Mishra, S., and Orozco, D. (2009). Evaluating the financial impact of branding using trademarks: a framework and empirical evidence. Journal of Marketing, 73, 154-166. 
Lu, J.W., and Beamish, P.W. (2006). SME internationalization and performance: Growth vs. profitability. Journal of International Entrepreneurship, 4 (1), 27-48.

Macchion, L., Moretto, A., Caniato, F., Caridi, M., Danese, P., Spina, G., and Vinelli, A. (2017). Improving innovation performance through environmental practices in the fashion industry: the moderating effect of internationalisation and the influence of collaboration. Production Planning \& Control, 28 (3), 190-201.

Malem, W. (2008). Fashion designers as business: London. Journal of Fashion Marketing and Management, 12 (3), 398-414.

Mamede, R.P., Fernandes, T.F., and Godinho, M.M. (2014). Patterns and determinants of trademarks in Portugal, in Hirsch-Kreinsen, H. \& Schwinge, I. (Eds.), Knowledge-Intensive Entrepreneurship in Low-Tech Industries, Edward Elgar Publishing, Cheltenham, UK, 95-116.

McDougall, P.P., and Oviatt, B.M. (1996). New Venture Internationalization, Strategic Change, and Performance: A Follow-Up Study. Journal of Business Venturing, 11 (1), 23-40.

Nash, J. (2019). Exploring how social media platforms influence fashion consumer decisions in the UK retail sector. Journal of Fashion Marketing and Management, 23 (1), 82-103.

Nastasiea, M., and Mironeasa, C. (2016). Performance measurement in small and medium sized enterprises. Revista Tehnomus, 23, 60-67.

Nelson, D.W., Moore, M.M. and Swanson, K.K. (2019). Fashion and social networking: a motivations framework. Journal of Fashion Marketing and Management, 23 (4), 608-627.

Nitzl, C., Roldan, J. L., and Cepeda, G. (2016). Mediation analysis in partial least squares path modeling: Helping researchers discuss more sophisticated models. Industrial Management \& Data Systems, $116(9), 1849-1864$.

OECD (2005). OECD SME and Entrepreneurship. Outlook: 2005, OECD Paris, page 17. 
Okazaki, S., and Taylor, C.R. (2013). Social media and international advertising: theoretical challenges and future directions. International marketing review, 30 (1), 56-71.

O'Cass, A., and Weerawardena, J. (2009). Examining the role of international entrepreneurship, innovation and international market performance in SME internationalisation. European journal of marketing, 43 (11/12), 1325-1348.

Padilla-Meléndez, A., and del Águila-Obra, A.R. (2013). Web and social media usage by museums: Online value creation. International. Journal of Information Management, 33 (5), 892-898.

Palacios-Marqués, D., Merigó, J.M., and Soto-Acosta, P. (2015). Online social networks as an enabler of innovation in organizations. Management Decision, 53 (9), 1906-1920.

Pallant, J. (2013). SPSS survival manual. McGraw-Hill Education (UK).

Paniagua, J., and Sapena, J. (2014). Business performance and social media: Love or hate? Business Horizons, 57 (6), 719-728.

Paniagua, J., Korzynski, P., and Mas-Tur, A. (2017). Crossing borders with social media: Online social networks and FDI. European Management Journal, 35 (3), 314-326.

Reinartz, W., Haenlein, M., and Henseler, J. (2009). An empirical comparison of the efficacy of covariance-based and variance-based SEM. International Journal of Research in Marketing, 26 (4), 332344.

Sarstedt, M., Ringle, C.M., Smith, D., Reams, R., and Hair, J.F., Jr. (2014). Partial least squares structural equation modeling (PLS-SEM): A useful tool for family business researchers. Journal of Family Business Strategy, 5 (1), 105-115.

Scuotto, V., Del Giudice, M., della Peruta, M.R., and Tarba, S. (2017). The performance implications of leveraging internal innovation through social media networks: An empirical verification of the smart fashion industry. Technological Forecasting and Social Change, 120, 184-194. 
Seethamraju, C. (2003). The value relevance of trademarks. In Hand, J. and Lev, B. (Eds), Intangible Assets: Values, Measures, and Risks, Oxford University Press, Oxford.

Shuman, J. C., and Seeger, J. A. (1986). The theory and practice of strategic management in smaller rapid growth firms. American Journal of Small Business, 11(1), 7-18.

Spithoven, A., Vanhaverbeke, W., and Roijakkers, N. (2013). Open innovation practices in SMEs and large enterprises. Small Business Economics, 41 (3), 537-562.

Tiago, M.T.P.M.B., and Veríssimo, J.M.C. (2014). Digital marketing and social media: Why bother? Business Horizons, 57 (6), 703-708.

Trainor, K.J., Andzulis, J.M., Rapp, A., and Agnihotri, R. (2014). Social media technology usage and customer relationship performance: A capabilities-based examination of social CRM. Journal of Business Research, 67 (6), 1201-1208.

Wallace, E., Buil, I. and Catalán, S. (2020). Facebook and luxury fashion brands: self-congruent posts and purchase intentions. Journal of Fashion Marketing and Management, forthcoming, https://doi.org/10.1108/JFMM-09-2019-0215

Weller, S. (2007). Fashion as viscous knowledge: fashion's role in shaping trans-national garment production. Journal of Economic Geography, 7, 39-66.

Whitehead, M. (1991). International franchising - Marks and Spencer: a case study. International Journal of Retail \& Distribution Management, 19 (2), 13-19.

Wigley, S.M., Moore, C.M., and Birtwistle, G. (2005). Product and brand: Critical success factors in the internationalisation of a fashion retailer. International Journal of Retail \& Distribution Management, 33 (7), 531-544

Zaheer, S., (1995). Overcoming the liability of foreignness. Academy of Management Journal, 38 (2), 341-363. 
Zahra, S.A., Ireland, R.D., and Hitt, M.A. (2000). International expansion by new venture firms: International diversity, mode of market entry, technological learning, and performance. Academy of Management, 43 (5), 925-950.

Zavrsnik, B. (2007). Critical success factors for international fashion retailers entering foreign markets. Fibres \& Textiles in Eastern Europe, 15 (63), 13-17.

Zhang, M., Guo, L., Hu, M., and Liu, W. (2017). Influence of customer engagement with company social networks on stickiness: Mediating effect of customer value creation. International Journal of Information Management, 37 (3), 229-240.

Zhou, H., Sandner, P.G., Martinelli, S.L., and Block, J.H. (2016). Patents, trademarks, and their complementary in venture capital funding. Technovation, 47, 14-22. 
Table I. Difference in means between SMEs with trademark and without trademark

\begin{tabular}{lccc} 
& With trademark & Without trademark & $\begin{array}{c}\text { Sig. } \\
(\mathbf{p}-\text {-value })^{\mathbf{a}}\end{array}$ \\
\hline N. firms (\%) & 32.4 & 67.6 & - \\
\hline PERFORMANCE & & & \\
Log Profit (loss) before taxation (mean) & 12.41 & 11.78 & 0.142 \\
Log EBITDA (mean) & $\mathbf{1 2 . 7 3}$ & $\mathbf{1 1 . 9 9}$ & 0.077 \\
\hline & & & \\
INTERNACIONALISATION & & $\mathbf{2 8 . 9}$ & 0.008 \\
International activity (\%) & $\mathbf{5 7 . 5}$ & \\
\hline \multicolumn{2}{c}{ a Significance was calculated considering Levene's test. }
\end{tabular}

Table II. Difference in means between SMEs with and without social media (website)

\begin{tabular}{lccc}
\cline { 2 - 4 } & With website & Without website & $\begin{array}{c}\text { Sig. } \\
\text { (p-value) }\end{array}$ \\
\hline N. firms (\%) & 52.9 & 47.1 & - \\
\hline & & & \\
PERFORMANCE & & & 0.036 \\
Log profit (loss) before taxation (mean) & $\mathbf{1 2 . 4 4}$ & $\mathbf{1 1 . 4 6}$ & 0.002 \\
Log EBITDA (mean) & $\mathbf{1 2 . 8 9}$ & $\mathbf{1 1 . 4 7}$ & \\
\hline
\end{tabular}

\section{INTERNATIONALISATION}

$\begin{array}{llll}\text { International activity (\%) } & \mathbf{5 0} & \mathbf{2 5} & 0.009\end{array}$

${ }^{\text {a }}$ Significance was calculated considering Levene's test.

Table III. Difference in means between SMEs with and without social media (social networks)

\begin{tabular}{lccc}
\cline { 2 - 4 } & $\begin{array}{c}\text { With social } \\
\text { networks }\end{array}$ & $\begin{array}{c}\text { Without social } \\
\text { networks }\end{array}$ & $\begin{array}{c}\text { Sig. } \\
\text { (p-value) }\end{array}$ \\
\hline N. firms (\%) & 47.1 & 52.9 & - \\
\hline PERFORMANCE & & & \\
Log profit (loss) before taxation (mean) & $\mathbf{1 2 . 6 2}$ & $\mathbf{1 1 . 5 5}$ & 0.021 \\
Log EBITDA (mean) & $\mathbf{1 3 . 0 6}$ & $\mathbf{1 1 . 6 1}$ & 0.001 \\
\hline & & & \\
INTERNATIONALISATION & & & \\
International activity (\%) & & 37 & 0.794 \\
\hline \multicolumn{2}{c}{ a Significance was calculated considering Levene's test. }
\end{tabular}


Table IV. Results summary for measurement model.

\begin{tabular}{lcccc} 
Variable & Indicator & Loadings $\boldsymbol{\lambda}$ & Composite Reliability & AVE \\
\hline Trademark & NT & 0.832 & 0.843 & 0,729 \\
& DT & 0.875 & & \\
\hline Social Media & CW & 0.935 & 0.903 & 824 \\
& SN & 0.880 & & 1 \\
\hline International Activity & IA & 1 & 1 & 0.972 \\
\hline Firm Performance & PBT & 0.912 & & 1 \\
\hline Firm Size & EBI & 0.956 & 1 & 1
\end{tabular}

$\mathrm{NT}=$ number of active trademark; DT $=$ if firm has a registered trademark; $\mathrm{CW}=$ if firm has a corporate website; $\mathrm{SN}=$ if firm has presence in social networks; $\mathrm{IA}=$ International Activity; EBI=EBITDA; PBT=Profit before taxation; FS=number of employees; FA=years since firm's foundation.

Table V. Discriminant validity (Fornell-Larcker)

\begin{tabular}{|l|c|c|c|c|c|c|}
\hline & FA & FS & IA & P & SM & T \\
\hline Firm Age (FA) & $\mathbf{1 . 0 0 0}$ & & & & & \\
\hline Firm Size (FS) & 0.190 & $\mathbf{1 . 0 0 0}$ & & & & \\
\hline International Activity (IA) & 0.363 & 0.253 & $\mathbf{1 . 0 0 0}$ & & & \\
\hline Firm Performance (P) & -0.079 & 0.228 & 0.317 & $\mathbf{0 . 9 3 4}$ & & \\
\hline Social Media (SM) & 0.065 & 0.223 & 0.174 & 0.328 & $\mathbf{0 . 9 0 7}$ & \\
\hline Trademark (T) & 0.138 & 0.139 & 0.323 & 0.131 & 0.163 & $\mathbf{0 . 8 5 4}$ \\
\hline
\end{tabular}

Table VI. Total, direct and indirect effects

\begin{tabular}{|l|c|c|c|c|c|c|c|}
\cline { 2 - 8 } \multicolumn{1}{c|}{} & \multicolumn{2}{c|}{$\begin{array}{c}\text { Total effect } \\
\text { Coeficient }\end{array}$} & \multicolumn{2}{c|}{$\begin{array}{c}\text { Direct effect } \\
\text { t-value }\end{array}$} & \multicolumn{3}{c|}{ Indirect effect (mediation) } \\
Coeficient & $\mathrm{t}$-value & \multicolumn{3}{c|}{ IC 95\% } \\
\hline $\mathrm{T} \rightarrow \mathrm{IA}$ & & & $0.302^{* * *}$ & 3.595 & & Bajo & Alto \\
\hline $\mathrm{T} \rightarrow \mathrm{P}$ & $0.098^{\dagger}$ & 1.267 & $-0.001^{\mathrm{ns}}$ & 0.012 & & & \\
\hline $\mathrm{SM} \rightarrow \mathrm{IA}$ & & & $0.124^{\text {ns }}$ & 1.163 & & & \\
\hline $\mathrm{SM} \rightarrow \mathrm{P}$ & $0.298^{* * *}$ & 2.993 & $0.257^{* *}$ & 2.621 & & & \\
\hline $\mathrm{IA} \rightarrow \mathrm{P}$ & & & $0.326^{* * *}$ & 3.455 & & & \\
\hline $\mathrm{FS} \rightarrow \mathrm{P}$ & & & $0.134^{*}$ & 1.753 & & & \\
\hline $\mathrm{FA} \rightarrow \mathrm{P}$ & & & $-0.239^{* *}$ & 2.551 & & & \\
\hline $\mathrm{T} \rightarrow \mathrm{IA} \rightarrow \mathrm{P}$ & & & & & $0.099^{* *}$ & 0.041 & 0.180 \\
\hline $\mathrm{SM} \rightarrow \mathrm{IA} \rightarrow \mathrm{P}$ & & & & & $0.041^{\mathrm{ns}}$ & -0.016 & 0.111 \\
\hline
\end{tabular}

$\dagger \mathrm{p}<0.1 ;{ }^{*} \mathrm{p}<0.05 ; * * \mathrm{p}<0.01 ; * * * \mathrm{p}<0.001 .{ }^{\mathrm{ns}}$ Not significant.

Trademark=T; Social Media=SM; International Activity=IA; Firm Performance=P; Firm Size=FS; Firm Age=FA. 


\section{Figure 1. Structural model}

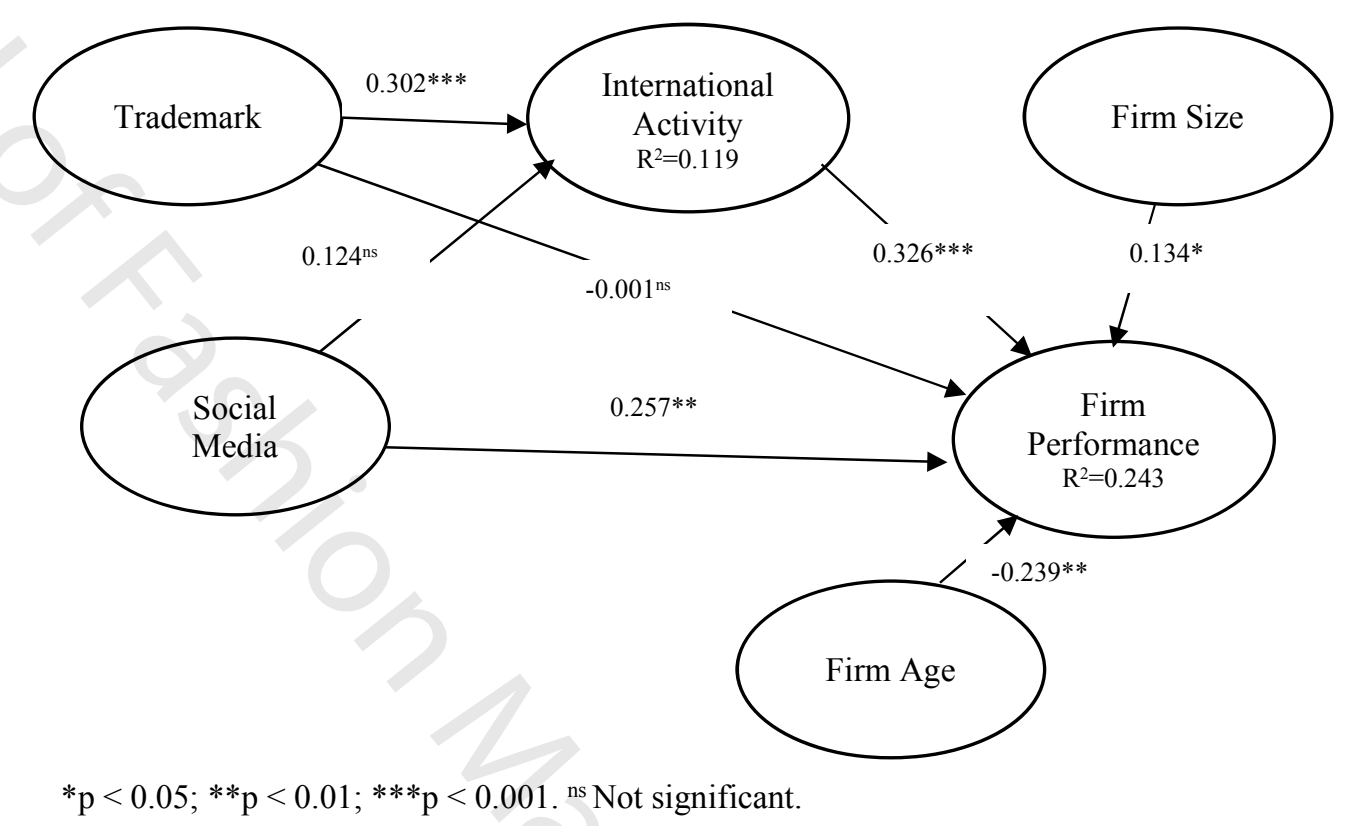

